\title{
Female Traditional Rulers in Eastern Nigeria: Eze-Ogo Alu Ibiam as a Case Study
}

\author{
F. A. OLASUPO \\ Obafemi Awolowo University, Ile-Ife, Nigeria
}

\begin{abstract}
Over a period of three years, research activities were embarked upon to verify the claim that female traditional rulers also exist in significant degree in the Eastern part of the country, particularly among the Igbo speaking people. The essence of the research was to find out whether there are some correlations between the findings here and those of other parts of Nigeria-Western and Northern part of the country in particular. The paper intends to find out how symmetrical and asymmetrical the finds female traditional rulers are with those of their counterparts in the Western and Northern part of the country.
\end{abstract}

Keywords: traditional ruler, female king, regent and gender

\section{Introduction}

Notable historians over the years have proven the existence of female traditional rulers in the Eastern part of Nigeria not only in the pre-colonial period but more recently in colonial and post-colonial periods while Bolanle Awe stated there was once an "Omu, which means Queen, at both Osomari where she was born and at Onitsha, where she achieved fame". The Omu in question was Okwei (Awe, 1992, p. 104). Moreover, Nwando Achebe proved there was once a female traditional ruler known as Ahebi Ugbabe, who "became the only woman in all of colonial Nigeria to be chosen to sit as a member of the Native Court as warrant chief" (Achebe, 2011, p. 105).

Recently, there have been more recent proofs of female traditional rulers in this region and the Igbo speaking areas of the Delta state. While Olasupo proves the existence of a sovereign female ruler in Unwana, Regent Alu Ibiam but now known as Ezeogo II of Unwana; Emordi and Osiki also proved the existence of female kings (traditional rulers) known as Omu in the Delta area of Asaba: Ogwashi Uku, Ubulu-Uku, lulehalbuso and others (Oseghale \& Osiki, 2010, p. 539; Agborh, 2007, p. 9).

In faraway Calabar is also Queen Duke, "which was given to her by the European traders who saw in her such qualities as royalty, elegance, grandeur, towering physique as well as the air of magnificence and celebrity, which surrounded her personality" (Akoda, 1999, p. 85).

As in Yorubaland, there are also three categories of female traditional rulers in Igboland: substantive female traditional ruler having sovereignty over both male and female in the community; female regency; and a gender balance in which there existed male and female kings as in Onitsha, OgwashiUku, Ubulu-Uku, luleha, Ibuso and others. But amongst the Baatonu people of northern Nigeria, one of these three categories-Regency - does not exist. The question is, to what extent are these female chieftaincy: female 
traditional sovereigns, regency and female kings, symmetrical and asymmetrical across the broader Nigerian spectrum? In my previous work on female traditional rulers, I have considered those of Western and Northern Nigeria. Now, it is the turn of Eastern Nigeria and its relativity with other regions.

\section{Sovereign Female Monarch}

The origin of the sovereign female monarch in Igboland in particular Eastern Nigeria in general is not yet certain but Achebe made a discovery that indicated that there was at least one in Igboland before the advent of colonialism in Nigeria. It was Monarch Ahebi Ugbabe, who the colonial authority incorporated into the system of warrant chiefs and the only woman known to have been a member of warrant chiefs in Eastern Nigeria. A different but similar case of colonial authority recognizing a woman as a monarch is the case of Queen Duke of Calabar who never made it to the point of being made a warrant chief. Thus, apart from these two, there are no known facts of women becoming sovereigns in this area (Eastern Nigeria) until September 29, 2012 when Regent AluIbiam was crowned as Ezeogo (Opara, 2012, p. 1).

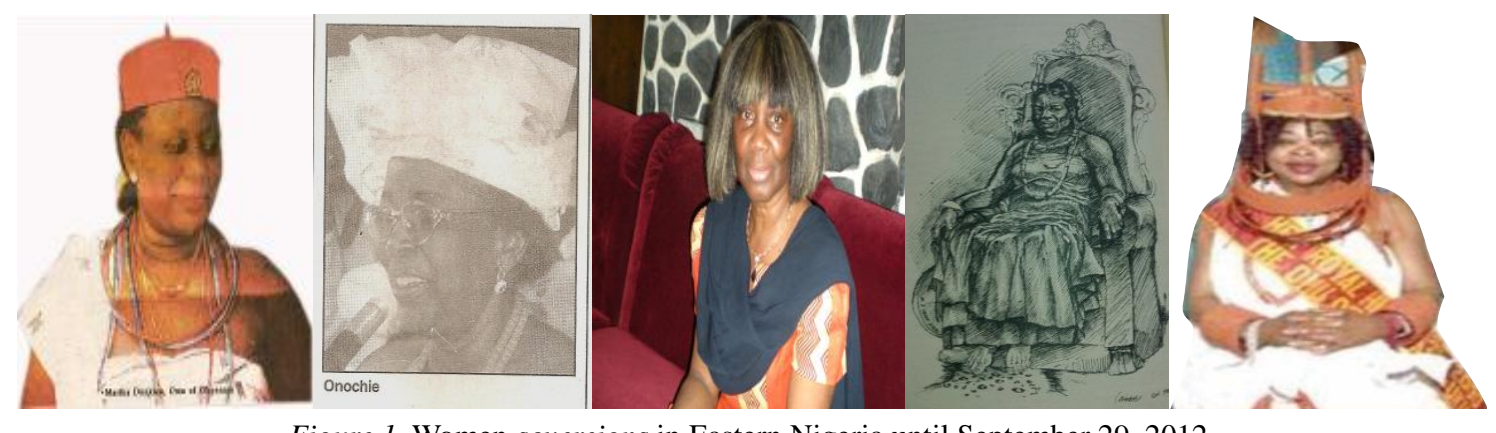

Figure 1. Women sovereigns in Eastern Nigeria until September 29, 2012.

The journey to the coronation was rough in three important and interesting ways. One, until now, no women had ever become the ruler of Unwana. The father of Princess Alulbiam who became one did so at the twilight of his life and after years of meritorious service as the Governor of Eastern Nigeria (The Nation newspaper of December 30, 2007, p. 54). He was EzeOgo I of Unwana. Secondly, just as her father was the first EzeOgo of Unwana, Princess AluIbiam became the first princess to become female Regent, not only in Unwana but the whole of Eastern Nigeria. Thirdly, her coronation as EzeOgo II of Unwana was a bit turbulent. Starting from when she became Regent, as presage to full and substantive female king, some disgruntled elements within the Unwana community were not comfortable with her resulting in her regency being subjected to electoral review. But each time this came up she had always won the support of the traditional council, "including standing for an election during which titled men, youths and women endorsed her re-election" as Regent (Online, AluIbiam in her father's shoes).

However, her coronation was to be the highest point in the theatrics of her challengers especially from Mr. Ikechukwu Njoku, whose opposition platform-Unwana Reformation Committee-described her coronation as "an aberration of the traditional norms of the community". According to them "it should be disregarded in its entirety as the matter was already in court and the youths and elders of the community had on June 15, 2012, crowned Mr. Ikechukwu Njokuas the rightful traditional ruler of the community" (Opara, 2012, p. 1). Regardless of the antics of few miscreants who felt that woman should not be a leader over them, Regent AluIbiam was “crowned as the Uwana-Afikpo's traditional ruler by a popular majority of the community". She bears the title Ezo-Ogo II of Unwana. 


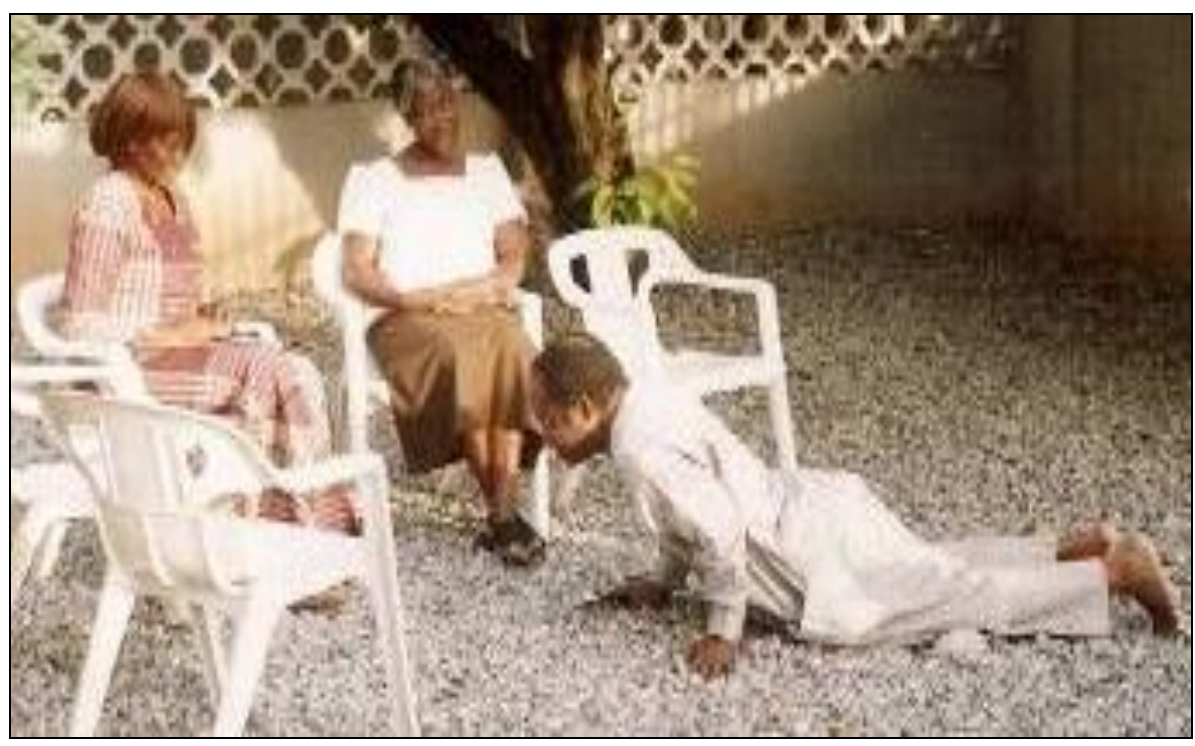

Figure 2. Queen Okpanam receiving homage from the coordinator Olasupo.

Note. In the pictures above, from left, are Omu (Queen) of Okpanam, Dr. Marthia Dunkwu; Omu of Onitsha, Mrs Onochia, former Regent of Unwanna, Princess AluIbiam, And the only Female Warrant Chief in the colonial days, Queen Ahebi Ugbage ; Omu of Oguwashi-Uku, Her Royal Highness, Mrs. Clara RafuaKinke; and at the bottom is the researcher, Olasupo, paying homage to the recently crowned Eze-Ogo II of Unwana, EzeAluIbiam, in Afigbo area of Eboyin State.

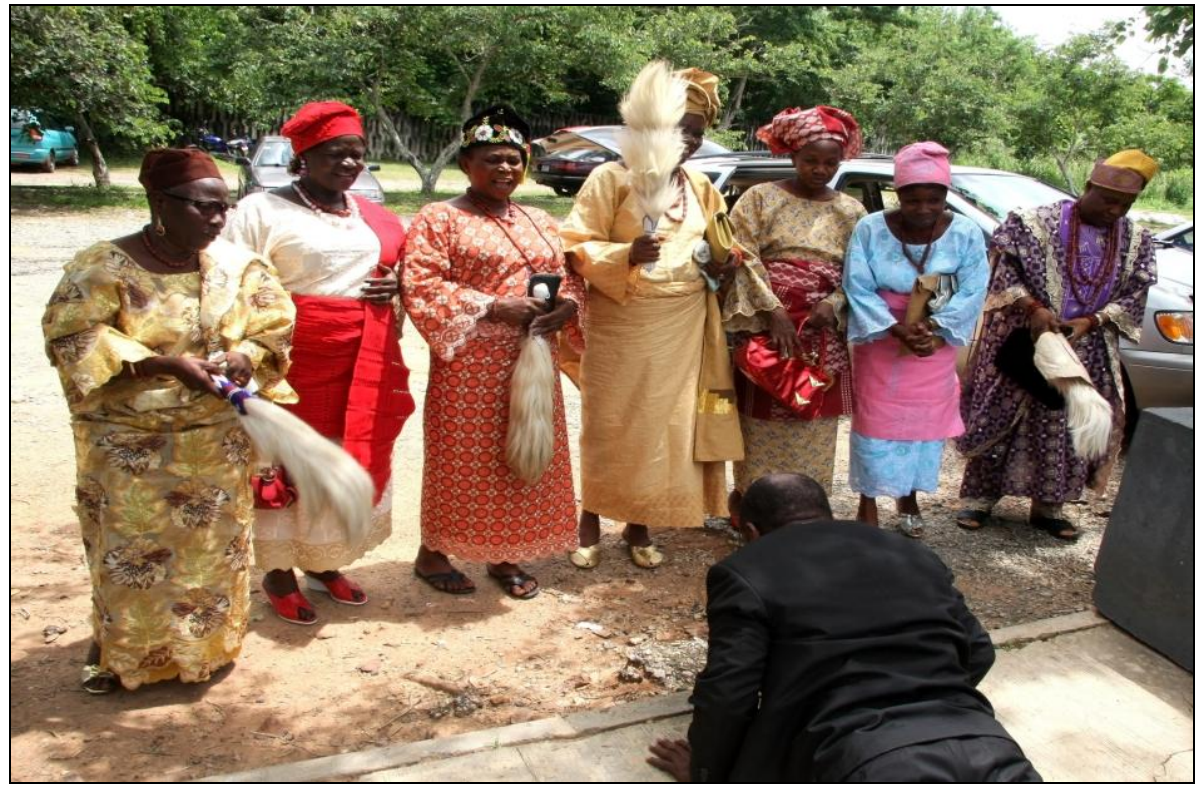

Figure 3. The Executives of Council of Ekiti State Regents receiving homage from the coordinator RGFIN, F.A Olasupo.

Note. Standing from left are Retired Regent Falade Moradeke Aladesanmi (President), Jinadu Temilola (PRO), Owoeye Juliana, Awolusi Esther (Vice President), Eunice Falade, Adebomi Adenike (Secretary), Ademuyi Madojutola, and Adeyemo Kehindo (Treasurer).

The female regency institution is a new phenomenon in Igboland. It is a traditional crisis management institution that came on board immediately after the death of an Oba (King) in specific Yoruba speaking areas 
of Ekiti, Ondo and Osun States. The stipulated minimum period of stay as regent in Yorubaland is three months with six months seen as the maximum period. How this became adopted to be in the eastern part of the country, for the first time, as was the case of Princess Alulbiam, is an interesting topic to investigate. Eze Ogo II narrated this herself. According to her:

I came back on holiday to visit my father, to see how he was doing. But then his health started failing, and I decided to stay with him for a while. And it turned out to be the very last period of his life. So, when he passed on, I decided to go back to Canada to carry on with my life there. But I was invited to take the Regency, caretaker traditional rulership. I was informed that it was going to be for a very short period, like a maximum of six month. But here I have been, running along for the past ten years. (Orisakwe, 2005, p. 29)

What is unstated but most likely to be the reason for the rationalization of the adoption of the female Regency institution in Igbo land for the first time, is AluIbiam's maternal background Miss Eudora Olayinka Sasegbon, delete later Lady Olayinka Onikepo Ibiam, was a Yoruba woman from the western part of Nigeria (Orisakwe, 2005, pp. 28-29). Female regency is known in the Yoruba parts of Ekiti, Ondo and Osun states. There could be some other areas where this institution of female regency exists but the states mentioned earlier are the bastion of the regency institution in Yorubaland. The theory behind this tradition is that,

Traditional Yoruba culture provides that the throne should not be totally vacant, particularly during interregnum... As a rule, Regents are largely selected among women in the ruling houses. If a male child is made the Regent, he may refuse to leave the throne at the appropriated time. This is why Regents are mostly chosen from women in the ruling houses. (Olomola, Ajuwon, \& Omotoso, 2003, pp. xx-xxi)

Over their neglect by the government as well as their male counterparts, Council of Ekiti State Regents (CESR) recently paid a protest visit to the coordinator, Research Group on Female Traditional Rulers in Nigeria (RGFIN) located in Department of Local Government Studies, Faculty of Administration of Obafemi Awolowo University. "Their mission, according to the President of the Council, Ex-Regent Falade, Moradeke Aladesanmi, is to call the attention of (RGFIN) to the puerile and insensate attitudes of some of their communities, Obas, Local Government and State government to their plight" (Olasupo, 2014b, p. 58). Figure 3 is the images of the Executives of Council of Ekiti State Regents.

If the Igbos copied this idea of female Regency from the Yorubas, there is something important that the Yorubas must also have copied from the Igbos - transition from Regency to sovereign monarch. After 16 years at Alu Ibiam Regency, the elders in Unwana that having passed all the necessary traditional tests including high performance, Regent AluIbiam was due to be elevated to substantive monarch and was accordingly elevated to this position on September 29, 2012. In the Yoruba areas of the Ekiti, Osun and Ondo states, woman regents in some places spend 10,20,30, 40 and even 60 years without being confirmed as substantive monarchs (Adegbola, 2014, p. 50; Olasupo, 2014b, p. 58; p. 33; Okwuofu, 2014, p. 30). Her Royal Highness, Eze-Ogo II has set a record for Yorubas to emulate.

\section{Omu}

The origin of Omu (Igbo gender balance in traditional governance) has a somewhat background. For Awe, the first Omu of Viz., appeared to be around 1872 to 1943. Oseghale and Osiki however state that the origin of Omuship, for Ubulu-Uku people of Delta State, could be traced back to 1349-1400. Regardless of the conflicting date, what is certain is that there still is a female traditional institution in Igbo land called Omu (Queen). Yet, another account from Onitsha says that "the stool of Omu (Queen) of Onicha has been vacant for 
more than hundred years now. Our last queen was Omu Nwagboka. She was from Ogbendida village and was married into the Egwuatu family of Ogbeotu. The Omu was never the wife of the King in Onicha but was appointed by the King"1. The Omu tradition flowed from Onitsha to Anioma, the Igbo speaking area of the Delta State, or the other way round, is a different issue altogether.

Like their Yoruba and Baatonu counterparts, women of advanced age in the past, were made Omu (female kings) (Agborh, 2007, p. 13). Again, like the Baatonu people, Omus normally are daughters of reigning Obis who had been married out or were of marriageable age and the persons so appointed as Omus remain in office until they died and new ones were appointed (Oseghale \& Osiki, 2010, p. 541). They, according to Oseghale and Osiki, were "women arm of male political institutions and their selections were oracular determined like their male counterparts".

Like their male counterparts, Obis, they had their own palaces and other insignia of office such as sword, drums and fan like those of male Obis (Oseghale \& Osiki, 2010, p. 543). Regarding their operations, they had their own cabinet (the OtuOmu) and their offices entailed both physical and spiritual responsibilities (Agborh, 2007, p. 13). Part of the duties of the Omus are presiding over matters, dispute settlement among women and the offering of "living" advices to their monarchs, especially on religious and administrative matters. In short, as Oseghale and Osiki put it, Omus are mini-kings in their small palaces in the sense that they are attended to by retinues of advisers (that included few men who the Omus had conferred with traditional titles) and domestic assistants (Oseghale \& Osiki, 2010, p. 542; Agborh, 2007, p. 13). Omus represented women folks in the council of state and were considered more powerful than Obis male chiefs (Oseghale \& Osiki, 2010, p. 542). In other words, Omus are female kings next to Obis in royalty in their various communities. This is very, very similar to Baatonu peoples' female traditional institutions. Among the Baatonu people of Baruten Local government in Kwara State, Female Emirs are next to the Male Emirs in the administrative structures of their communities (Olasupo, 2014a)

Statistics of male Obis and female Obis in Igbo land and Igbo speaking areas of Delta States are: Onitsha: Obi of Onitsha (Alfred Achebe) and Omu (female Obi) of Onitsha (Onocha); Okpanam: HRM. Obi V.A. Nwaokobia IV and the Omu (female Obi) Dr. Marthia Dunkwu; Ogwashi-Uku: Obi Prof. Chukwuka Okonjo and Omu (female Obi) Clara RafuaKinke; Ibusa: Obi Prof. Chelunor Nwoboshi and Omu (female Obi) of Ibusa (whose name is not yet known). There are many more that are yet to be explored.

Today however, the institution itself and the roles performed by these women monarchs in gender balance are gradually fading out particularly in those communities where, according to Agborh, "Omus are not literate enough and are still holed up by the ancient traditions. But for the Omus that are highly educated like Dr. Martha Dunkwu, the Omu of Okpanam and her Royal Highness, Mrs. Clara Rafua Kinke, the Omu of Ogwashi, they have "injected positive ideas into the OtuOmu and focused it to bring positive changes to lives of women in their communities" (Agborh, 2007, p. 13).

\section{Conclusion}

It has been proven beyond reasonable doubt that three types of female traditional rulers institutions exist in Nigeria: Sovereign Substantive female traditional rulers, Female Regency in only Igbo and Yoruba land, and of course the most spectacular one, gender balance in traditional ruler ship (Male king-Female king). Note that the

\footnotetext{
${ }^{1}$ Retrieved from http://www.onitshaadounion.com/files/ABOUTUS/AdoUnionHistory0.html
} 
issue of gender is African Origin and not 1971 Beijing declaration.

Like in other parts of Nigeria, a substantive female traditional ruler, Eze-Ogo, Alu Ibiam, has been found in Eboyin State to join her counterparts in the West and the North. Just as there is only one substantive sovereign female traditional ruler in the East so is there only one so far found in the West. Oba Mary Alari Igbayilola, though dead now, is found in Maya, a town very close to Ogbomosho in Oyo State. Surprisingly but interestingly, two sovereign substantive female traditional rulers are found in the North; Kumbada in Niger State and Ganye in Adamawa State. Both were duly turbaned by Emirs of Mina and Ganye respectively.

Interestingly, apart from public opinion, institutional pressures have begun to ratchet-up on the question of female traditional rulers in Nigeria. Arguably, the statue of traditional rulers in today's modern Nigerian government is said to be that of civil servant and must therefore obey civil service rule. A test of this was the case between the late Emir of Kano, Alhaji Ado Bayero and one of his kingmakers, Alhaji Aminu Babba Dan Agundi as the DarkinMaituta (one of the four kingmakers of Kano) purportedly sacked by Ado Bayero way back in 2003 and, had to be reversed by Justice Mohammed Salamato (Magbo, 2011, p. 63).

To fault sacked decision of Ado Bayero and his traditional council, Justice Salamato relied not on the emirate traditional process but that of the statute of traditional rulers in the state. Justice Mohammed Salamato resolved the case in favor of the fact that (1) traditional rulers are public servants; (2) the emirate council itself is a creation of statue adding that it derives its own life from the Local Government Laws of Kano State; (3) that kingmakers are invested with high public responsibilities in their domains; and (4) that the deposed kingmaker's office did not exist at the pleasure of the Emir of Kano, but regulated by the rules of the public service of the state (Magbo, 2011, p. 63).

Another booster to this was the recent Supreme Court judgment that "nullified age long tradition in some parts of Igbo land which excluded women from such inheritance". By this Supreme Court ruling, "wives and daughters can share in the inheritance of their spouses or fathers" (Onu \& Odogwu, 2014, p. 37). Expectedly, this generated heated arguments among traditional rulers, community leaders and opinion molders in the Eastern part of Nigeria. For the Chairman of Anambra North Traditional Council, Igwe Rowland Odegbo, the judgment "is in line with international practice". Igwe Odegbo who "is traditional ruler of Nteje in Oyi Local Government area, wondered why men should be enjoying everything about women but once their husband is dead they became pariahs". "My opinion is that our female children and women are part of our community and part of us. It is inhuman to deny them inheritance. Why can't they inherit their fathers' properties" (Onu \& Odogwu, 2014, p. 37).

For retrogressive and ultra-patriarchal traditional ruler of Njikoka Local Government Area, Chijioke Nwankwo, and his callous counterpart, Igwe Elias Nneli, from Umueje, in Ayamelum Council Area, "the judgment was a way of rubbishing the Igbo culture and tradition; arguing that customary courts were supposed to deal with such cases". In any case the "Oracle", Supreme Court, has spoken and it is unappeasable.

These two judgments have serious and positive implication on the vex question of Princess becoming female traditional rulers; Regents transmuting to substantive female traditional rulers; and gender-balance in traditional rulership (male king and female king) as upheld by some cultures in Nigeria.

Thus, these discoveries are parts of intensive two decades of research on traditional rulers across Nigeria. Authorities at all levels of government in Nigeria should take note of these and accord recognition to 
institutions of female traditional rulers in Nigeria.

\section{References}

Achebe, N. (2011). The female king of colonial Nigeria: Ahebi Ugbade. USA: Indiana University Press. Adegbola, T. (2014, May 14). Female traditional rulers need to be recognized. Nigerian Tribune.

Agborh, A. (2007, July 9). Queen mother in N/ Delta society. Nigerian Tribune.

Akoda, W. E. (1999). The political and religious roles of Efiki Women in pre-colonial Calabar. Calabar Journal of Religious Studies, 1(1), 84-95.

Awe, B. (1992). Women and politics in historical perspective in women and politics in Nigeria. Ikeja: Malt house Press Limited. Magbo, D. (2011, July 17). Royal rumble: The unmaking of an Emir. Sunday Sun.

Olasupo, F. A. (2014a). A case for female traditional rulers. The Guardian Newspaper, June 29 and July 6.

Olasupo, F. A. (2014b). Revolution in emirate system in Nigeria. International Relations and Diplomacy, 2(3), 212-226.

Olomola, I., Ajuwon, B., \& Omotoso, D. (Eds.). (2003). Prominent traditional rulers of Yorubaland. Ile-Ife: Obafemi Awolowo University \& Celebrity Publication Limited, Ibadan.

Onu, N., \& Odogwu, E. O. (2014, April 29). Female inheritance: More communities react to supreme court verdict. The Nation Newspaper.

Okwuofu, O. (2014, May 14). Royal rumble: Women traditional rulers complain of neglect, suppression. The Nation Newspaper.

Opara, G. (2012). Controversy trails Ibiam coronation as Unwana Monarch. Blueprint.

Orisakwe, S. (2005, August 13). Akanu Ibiam's house should be a national monument. The Guardian Newspaper.

Oseghale, B. E., \& Osiki, O. M. (2010). Women chieftaincy institutions: A comparative study of the Oluaship title in Luleha Clan, Edo State and the Omushiptitle in Ubulu-Uku, Delta State, 1400-2000. In T. Babawale, A. Alao \& B. Adesoji (Eds.), The chieftaincy institution in Nigeria (p. 539). Lagos: Center for Black African Arts and Culture.

The Nation. (2007, December 30). AkanuIbiam resurrects at Okotie's church. The Nation Newspaper. 